Playing God: The Bible on the Broadway Stage by Henry Bial

Ann Arbor: University of Michigan Press, 2015, 240 pp, ISBN 9780472072927 (paperback)

\title{
Joshua Edelman
}

Manchester Metropolitan University

Henry Bial's new book offers a history of Broadway plays and musicals that derive from Biblical texts and narratives. He starts with the grandly spectacular 'toga plays' (p. 35) of the turn of the century such as Ben Hur (1899) (which he usefully calls 'Biblical fan fiction' in the title of the second chapter), and moves on to Broadway adaptations of the creation narrative, the story of Noah, and the Book of Job. He ends with a look at the mega-musicals Jesus Christ Superstar (1971) and Godspell (1976), as well as a pair of fascinating Broadway failures: I'm Solomon (1968) and Hard Job Being God (1972).

Bial makes two key choices in putting this book together that shape his overall project. First, he chooses to write a history of a certain strand of twentieth-century theatre work, rather than a critical picking-apart of the conceptual differences between, say, the differing appeals of ritual and theatre, the authorities of scripture and script, or theological doctrine and aesthetic affect. This is an understandable choice. These are muddy theoretical waters indeed, and when Bial does seek to dip his toe into them, he does so through reference to others who have worked in this area: Shimon Levy on dramatic adaptation of the Bible, Jill Stevenson on the affective performances of American evangelical Christianity, and Linda Hutcheson on adaptation theory. ${ }^{1}$. This historical focus means that Bial constantly risks privileging narrative over explanation. This is not inherently a bad thing: theatrical practice frequently is richer and more usefully complex than our attempts to theorize it. But it does mean that some of the tensions that Bial's history brings out cannot be addressed as squarely as readers might wish. For example, Bial's discussion of the smash-hit musical (and Pulitzer Prize-winner) The Green Pastures (1930) shows that critics of the time found this version of the creation myth performed by an all black cast sincere, sweet, and unproblematic. Certainly, Bial's sources clearly 'betra[y] white assumptions' that black performers were 'primitive and childlike' (p. 74), but what does it suggest about the ways in which popular culture reinforces, develops or critiques those

1 Shimon Levy, The Bible as Theatre (Brighton: Sussex Academic Press, 2000); Jill Stevenson, Sensational Devotion: Evangelical Performance in Twenty-First Century America (Ann Arbor: University of Michigan Press, 2013); Linda Hutcheson, A Theory of Adaptation (London: Routledge, 2006). 
assumptions? A closer look at theories of racial performance and minstrelsy might have added usefully to his analysis.

Second, Bial's focus is squarely on Broadway, not on the wider New York (or American) theatre scene. This means that he is interested in commercial theatre, rather than the century of experiments that theatre artists have made at the boundaries of ritual, religion and performance. As a consequence, success, whether measured in length of run or critical reception or money made, becomes a more important metric for him than artistic merit as such. Bial works on the assumption that there is a link between the reception of a piece and the ways in which it speaks to the condition of the American public. This is Broadway history as the social history of popular American religiosity. In that, the invocation of rather vague concepts such as reverence, respect or sincerity to justify the success of one work or the failure of another is not a critical failing; it is exactly the point. Popular religiosity has more of a need for fuzzy conceptual lodestars than for rigid intellectual coherence, and Bial usefully describes the social negotiations that this situation demands.

Bial's history is well-researched, self-reflexive and a pleasure to read. But because of these two choices, he leaves a few theoretical knots frustratingly tied. His rubric of four performative strategies for approaching the Bible on stage - spectacle, authenticity, sincerity, and irony - are useful, but they overlap and blend with one another so frequently that they do not seem distinct. If authenticity is not an (unsupportable) naturalist claim to historical reenactment but rather an affective claim that something feels real, how is that not a form of (or a claim to) sincerity? In addition, evangelical Christianity frequently equates that affect of authentic spirituality with the spectacular or overwhelming, what Bial calls at one point 'a "wow" moment that opens the spectator to the possibility of transcendence' (p. 51). Does this reduce Bial's four strategies down to a dichotomy between an overwhelming feeling of awe and majesty that audiences equate with (Christian) spirituality and an ironic, critical, neurotic, comic, worldly and-oh, let's just say it-Jewish approach? And is this latter approach doomed to be less successful than the former if it doesn't take back seat to a catchy score? The case Bial offers that seems to unite both sides of this dichotomy (and thus undermine it) is Archibald MacLeish's J.B. (1958), but his excellent development of this example does not alter his theoretical framework.

Perhaps part of the difficulty - which gets to the Christian/Jewish tension running throughout the book - is that Bial's topic is the Bible, but his focus is on religious life. The two are not the same. Judaism has a different relationship to its Bible than Christianity has to its, and those Bibles have a different role in the religious life of different Christians and Jews. So the 
Bible is not a very good metonym for religious experience or religion as such. Equating the biblical with the religious causes problems. For instance, Bial traces out the problematics of a human actor portraying God, showing the different ways in which producers have tried to solve this problem, but he says very little about why it is that casting a person in the role of God is so difficult. The answer, of course, is because this is a religious question and not one that can be satisfactorily answered by an appeal to the Biblical text. Bial's statement that 'blasphemy does not rhyme with box office' (p. 25) may not be philosophically or theologically satisfying, but it succeeds in naming the historical force that has pushed Broadway theatre towards a vaguely reverential attitude toward religion for most of its history.

Despite my theoretical misgivings, this book is a timely and valuable history of the popular engagement between American religion and the commercial stage. It should be a fixture on the library shelf for those with an interest in Broadway history, American social history, and the links between theatre and religion. 